\title{
Impact of surface coating and particle size on the uptake of small and ultrasmall superparamagnetic iron oxide nanoparticles by macrophages
}

This article was published in the following Dove Press journal:

International Journal of Nanomedicine

9 October 2012

Number of times this article has been viewed

\author{
Shigeyoshi Saito' \\ Mana Tsugeno' \\ Daichi Koto' \\ Yuki Mori ${ }^{2}$ \\ Yoshichika Yoshioka² \\ Satoshi Nohara ${ }^{3}$ \\ Kenya Murase' \\ 'Department of Medical Physics and \\ Engineering, Division of Medical \\ Technology and Science, Faculty of \\ Health Science, Graduate School \\ of Medicine, ${ }^{2}$ Biofunctional Imaging \\ Lab, Immunology Frontier Research \\ Center (WPI-IFReC), Osaka \\ University, Osaka, Japan; ${ }^{3}$ The Nagoya \\ Research Laboratory, Meito Sangyo \\ Co, Ltd, Kiyosu, Aichi, Japan
}

Purpose: Magnetic resonance imaging (MRI) using contrast agents like superparamagnetic iron oxide (SPIO) is an extremely versatile technique to diagnose diseases and to monitor treatment. This study tested the relative importance of particle size and surface coating for the optimization of MRI contrast and labeling efficiency of macrophages migrating to remote inflammation sites.

Materials and methods: We tested four SPIO and ultrasmall superparamagnetic iron oxide (USPIO), alkali-treated dextran magnetite (ATDM) with particle sizes of 28 and $74 \mathrm{~nm}$, and carboxymethyl dextran magnetite (CMDM) with particle sizes of 28 and $72 \mathrm{~nm}$. Mouse macrophage RAW264 cells were incubated with SPIOs and USPIOs, and the labeling efficiency of the cells was determined by the percentage of Berlin blue-stained cells and by measuring $\mathrm{T}_{2}$ relaxation times with 11.7-T MRI. We used trypan blue staining to measure cell viability.

Results: Analysis of the properties of the nanoparticles revealed that ATDM-coated $74 \mathrm{~nm}$ particles have a lower $\mathrm{T}_{2}$ relaxation time than the others, translating into a higher ability of MRI negative contrast agent. Among the other three candidates, CMDM-coated particles showed the highest $\mathrm{T}_{2}$ relaxation time once internalized by macrophages. Regarding labeling efficiency, ATDM coating resulted in a cellular uptake higher than CMDM coating, independent of nanoparticle size. None of these particle formulations affected macrophage viability.

Conclusion: This study suggests that coating is more critical than size to optimize the SPIO labeling of macrophages. Among the formulations tested in this study, the best MRI contrast and labeling efficiency are expected with ATDM-coated $74 \mathrm{~nm}$ nanoparticles.

Keywords: ultrasmall superparamagnetic iron oxide, cultured mouse macrophage cells, surface coating, particle size, MRI

\section{Introduction}

The use of nanoparticles for cellular imaging is among the most important clinical breakthrough of the past decade. In particular, superparamagnetic iron oxide (SPIO) nanoparticles enhance contrast in magnetic resonance imaging (MRI), which allows clinicians to monitor anatomical, physiological, and molecular changes during the evolution of a disease or treatment. Following intravenous injection, these nanoparticles accumulate in macrophages residing in the liver, bone marrow, and spleen, as well as tumors and sites of inflammation. Accordingly, applications include the detection of inflammatory diseases, in vivo stem cell tracking, ${ }^{1}$ hyperthermia therapy, ${ }^{2}$ lymph node detection, ${ }^{3}$ and anticancer drug delivery. ${ }^{4}$

The current applications for SPIO nanoparticles are limited because these relatively large particles, with an average diameter of $80 \mathrm{~nm}$, are rapidly internalized by the
Correspondence: Kenya Murase Department of Medical Physics and Engineering, Division of Medical Technology and Science, Faculty of Health Science, Graduate School of Medicine, Osaka University, I-7 Yamadaoka, Suita, Osaka 565-087I, Japan

Tel +8 I 66879257 I

Fax +8I $66879257 \mid$

Email murase@sah.med.osaka-u.ac.jp 
mononuclear phagocytic system of the liver and the spleen. This problem is currently addressed by the development of ultrasmall superparamagnetic iron oxide (USPIO) nanoparticles $(<50 \mathrm{~nm}) .{ }^{5}$ In vivo studies recently showed that USPIO nanoparticles of $35 \mathrm{~nm}$ in diameter have a longer half-life in the circulation system, allowing the labeling of macrophages migrating to remote areas. ${ }^{6,7}$ These studies opened the door to a number of new applications for molecular imaging because macrophages migrate and accumulate at sites of inflammation, ${ }^{8}$ autoimmune neuritis, ${ }^{9}$ renal ischemia, ${ }^{10}$ and solid organ transplant rejection. ${ }^{11}$ The use of USPIO agents has allowed for the direct visualization of macrophage infiltration of carotid atheroma in clinical study. ${ }^{12,13}$ The surface coating of USPIO nanoparticles also influences their stability and cellular uptake by macrophages. ${ }^{6}$ Dextran-based coatings are preferred because of their low toxicity and they are biodegradable. ${ }^{14}$ For instance, dextran-coated SPIO nanoparticles and ferucarbotran are approved for liver MRI. Moreover, carboxydextran-coated SPIO nanoparticles have undergone clinical trials for MRI evaluation of lymph node metastasis ${ }^{15,16}$ however, the impact of USPIO nanoparticles size and dextran coating composition on the uptake by macrophages has not been determined.

The aim of the present study is to determine the impact of particle size and surface coating on the cellular uptake and relaxing time of SPIO nanoparticles in mouse macrophages by MRI and microscopy. The USPIO (28 nm) and SPIO (72 and $74 \mathrm{~nm}$ ) nanoparticles were coated with alkali-treated dextran (ATDM) or carboxymethyl dextran (CMDM).

\section{Material and methods}

\section{Ultrasmall superparamagnetic iron oxides}

We tested four types of SPIO and USPIO contrast agents. ATDM (surface voltage potential: $-15 \mathrm{mV}$ ) was tested with particle sizes of 28 and $74 \mathrm{~nm}$. CMDM (surface voltage potential: $-24 \mathrm{mV}$ ) was tested with particle sizes of 28 and $72 \mathrm{~nm}$. All SPIO and USPIO compounds were purchased from the Meito Sangyo Company, Ltd (Aichi, Japan). ${ }^{17}$

\section{Cell culture of mouse macrophage RAW264 cells}

The mouse macrophage cell line RAW264 was provided by the RIKEN BioResource Center (RIKEN Tsukuba Institute, Tsukuba, Ibaraki, Japan). RAW264 cells $\left(1 \times 10^{6}\right)$ were cultured in minimum essential medium (SigmaAldrich, Tokyo, Japan), 10\% fetal calf serum (Nichirei Corporation, Tokyo, Japan), and $0.1 \mathrm{mM}$ nonessential amino acids (Sigma-Aldrich) in $93 \mathrm{~mm} \times 21 \mathrm{~mm}$ Petri dishes
(IWAKI, Tokyo, Japan) with $18 \mathrm{~mm}$ square cover glasses (Matusnami Glass Ind, Ltd, Osaka, Japan). All cultures were incubated with $5 \% \mathrm{CO}_{2}$ at $37^{\circ} \mathrm{C}$.

\section{Measurement of SPIO and USPIO T 2 relaxation times}

The contrast of proton MRI images depends on the relaxation times of the nuclear magnetization $\left(\mathrm{T}_{1}\right.$, longitudinal; $\mathrm{T}_{2}$, transverse). Iron oxide nanoparticles primarily affect $\mathrm{T}_{2}$ and work as negative contrast agents. A high intracellular concentration of SPIO and USPIO nanoparticles results in the reduction of $T_{2}$ relaxation time. Prior to the MRI experiment, the concentrations of USPIO particles were adjusted to $0.005 \mathrm{mg} \mathrm{Fe} / \mathrm{mL}$ and prepared in five sample tubes with water samples serving as controls. MRI experiments for the three times measurements of the $\mathrm{T}_{2}$ relaxation times were performed on an 11.7-T MRI scanner (Bruker BioSpin, Ettlingen, Germany) and used a volume RF coil with a $25 \mathrm{~mm}$ inner diameter for transmission and reception (m2m Imaging Corp, Cleveland, $\mathrm{OH}$ ). $\mathrm{T}_{2}$ mapping was performed using a multislice, multiecho spin-echo sequence (repetition time $=3000 \mathrm{~ms}$; slice thickness $=1 \mathrm{~mm}$; field of view $=25.6 \times 25.6 \mathrm{~mm}$; matrix $=128 \times 128$; slice orientation $=$ transaxial; number of repetitions $=1$ ) with echo times ranging from 10 to $100 \mathrm{~ms}$ in steps of $10 \mathrm{~ms}$. $\mathrm{T}_{2}$ maps were calculated from a single exponential fitting of MRI signal intensities at each echo time point.

\section{Measurement of USPIO-labeling efficiency}

The experiments were conducted to measure the $\mathrm{T}_{2}$ relaxation times of the macrophages labeled with SPIO or USPIO nanoparticles. All USPIO particles were dissolved in the cell growth medium at a concentration of $0.3 \mathrm{mg} \mathrm{Fe} / \mathrm{mL}$, which is similar to the concentration used in another published report. ${ }^{18}$ Cells $\left(2 \times 10^{6}\right)$ were incubated with medium containing USPIO particles for 1,2 , or $4 \mathrm{~h}$ (same time points noted in a previous report) $)^{19}$ at $37^{\circ} \mathrm{C}$ under $5 \% \mathrm{CO}_{2}$. After incubation, the medium was removed by two washes with phosphatebuffered saline (PBS) followed by fixation of the cells for 30 min with $7.5 \%$ formalin. The presence of iron oxides in the RAW264 cells was detected by staining with Berlin blue $\left(\mathrm{KFe}(3) \mathrm{Fe}(2)(\mathrm{CN})_{6}\right.$ ) (Wako Pure Chemical Industries, Ltd, Osaka, Japan ${ }^{20}$ for $20 \mathrm{~min}$. After washing away the Berlin blue with PBS, the cell nuclei were counter-stained with nuclear fast red for $5 \mathrm{~min}$. The nuclear fast red was removed by washing with PBS three times, and the cell specimens were fixed to the cover glass. For each experiment, the labeling 
efficiency of each type of USPIO nanoparticle was assessed visually by three observers using a BZ-9000 microscope (Keyence Corporation, Osaka, Japan). The labeling efficiencies (percentages of SPIO/USPIO uptake) were qualitatively assessed from the microscope images in three independent experiments by estimating the number of iron-positive cells within five randomly selected $200 \mu \mathrm{m}^{2}$ fields.

\section{Viability of USPIO-labeled cells}

We used trypan blue (Sigma-Aldrich) staining to measure cell viability. Viable cells are not stained by trypan blue, while dead and lysed cells are stained. All USPIO particles were dissolved in cell growth medium at a concentration of $0.3 \mathrm{mg} \mathrm{Fe} / \mathrm{mL}$, which is a lower concentration when compared to a sample test because the concentrations of SPIO and USPIO in macrophage cells were lower than sample SPIO and USPIO concentrations. Cells $\left(2 \times 10^{6}\right)$ were incubated in a medium containing USPIO particles for 1,2 , or $4 \mathrm{~h}$ at $37^{\circ} \mathrm{C}$ under $5 \% \mathrm{CO}_{2}$. After incubation, the medium was removed with two washes of PBS and the cells were fixed with formalin. Cells were stained with trypan blue for $10 \mathrm{~min}$ and the viable and dead cells were counted under a microscope. The percentages of viable cells were qualitatively assessed by counting the number of trypan blue-positive cells within five randomly selected $200 \mu \mathrm{m}^{2}$ fields. The cell viability was calculated at least thrice and an average was taken.

\section{Measurement of labeled cells using I I.7-T MRI}

All USPIO nanoparticles were dissolved in cell growth medium at a concentration of $0.3 \mathrm{mg} / \mathrm{mL}$. RAW264 cells $\left(2 \times 10^{6}\right)$ were incubated with medium containing USPIO particles for $30 \mathrm{~min}$ at $37^{\circ} \mathrm{C}$ under $5 \% \mathrm{CO}_{2}$. After incubation, the medium was removed by two washes with PBS and the cells were fixed with formalin. The concentration of RAW264 cells was adjusted to $4 \times 10^{6}$ cells $/ \mathrm{mL}$ and the cells $(0.5 \mathrm{~mL})$ were dissolved in $0.1 \%$ agarose gel $(0.5 \mathrm{~mL})$ to give a final concentration of $2.0 \times 10^{6}$ cells $/ \mathrm{mL}$. The sample temperature was maintained at approximately $23^{\circ} \mathrm{C}$ and the cells were imaged after settling into a pellet by gravity. For measurement of $\mathrm{T}_{2}$ relaxation time, $\mathrm{T}_{2}$ mapping was performed using a multislice multiecho spin-echo sequence (repetition time $=3000 \mathrm{~ms}$; slice thickness $=1 \mathrm{~mm}$; field of view $=25.6 \times 25.6 \mathrm{~mm}$; matrix $=128 \times 128$; slice orientation $=$ transaxial; number of repetitions $=1$ ) with echo times ranging from 10 to $100 \mathrm{~ms}$ in steps of $10 \mathrm{~ms}$. $\mathrm{T}_{2}$ maps were calculated from a single exponential fitting of MRI signal intensities at each echo time point. The measurements of labeled cells using 11.7-T MRI was repeated thrice.

\section{Statistical analysis}

All statistical analysis was performed using Prism (version 5; GraphPad Software Inc, La Jolla, CA). One-way analysis of variance with the Bonferroni correction was applied in order to compare changes in percentages of SPIO and USPIO uptake, cell viability, and $\mathrm{T}_{2}$ relaxation times for all SPIO/USPIO nanoparticles and labeled cells. $P<0.05$ was considered significant.

\section{Results}

\section{$\mathrm{T}_{2}$ relaxation time measurements of USPIO nanoparticles}

The MRI contrast provided by each type of nanoparticle formulation was compared by measuring the $\mathrm{T}_{2}$ relaxation

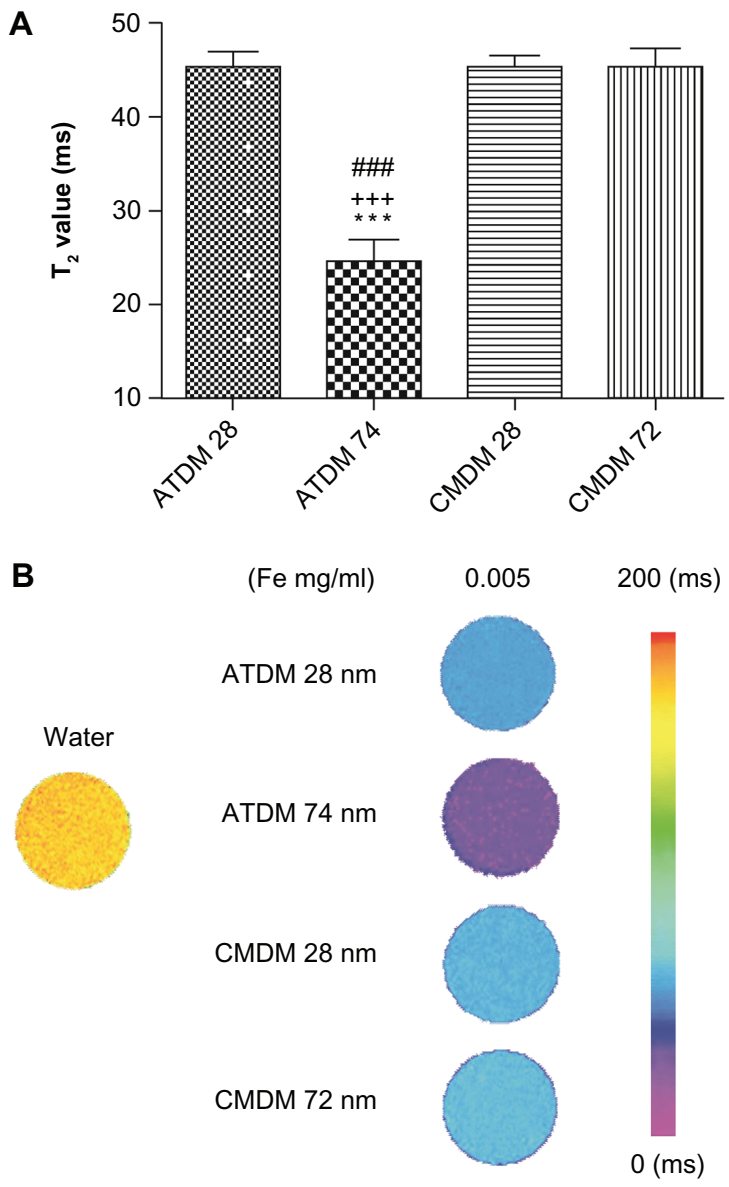

Figure I Relaxation time of two SPIO/USPIOs. (A) $\mathrm{T}_{2}$ maps of control sample ( $127.5 \pm 0.5 \mathrm{~ms}$ ) for ATDM and CMDM, 28, 72, and $74 \mathrm{~nm}$, at 0.005 and $0.01 \mathrm{mg} / \mathrm{mL}$. The color scale represents $T_{2}$ values from $0 \mathrm{~ms}$ to $200 \mathrm{~ms}$. (B) Graphical representation of $\mathrm{T}_{2}$ relaxation time of each of the nanoparticles.

Notes: ${ }^{* * *} P<0.001$, significant difference vs ATDM $28 \mathrm{~nm} .{ }^{+++} P<0.001$, significant difference vs CMDM $28 \mathrm{~nm}$.

Abbreviations: SPIO, superparamagnetic iron oxide; USPIO, ultrasmall superparamagnetic iron oxide; ATDM, alkali-treated dextran magnetite; CMDM, carboxymethyl dextran magnetite. 
time. At $0.005 \mathrm{mg} \mathrm{Fe} / \mathrm{mL}, \mathrm{T}_{2}$ relaxation time of the $74 \mathrm{~nm}$ ATDM-coated nanoparticles was lower than for the other three formulations (Figure 1A). Since a low $\mathrm{T}_{2}$ relaxation time translates into a high MRI negative contrast, these data suggest that ATDM-coated SPIO nanoparticles would provide the best MRI images among these formulations (Figure 1B).

\section{Evaluation of in vitro USPIO labeling efficiency by microscopy}

Microscopy analysis was used to compare the labeling efficiency of each nanoparticle formulation in terms of
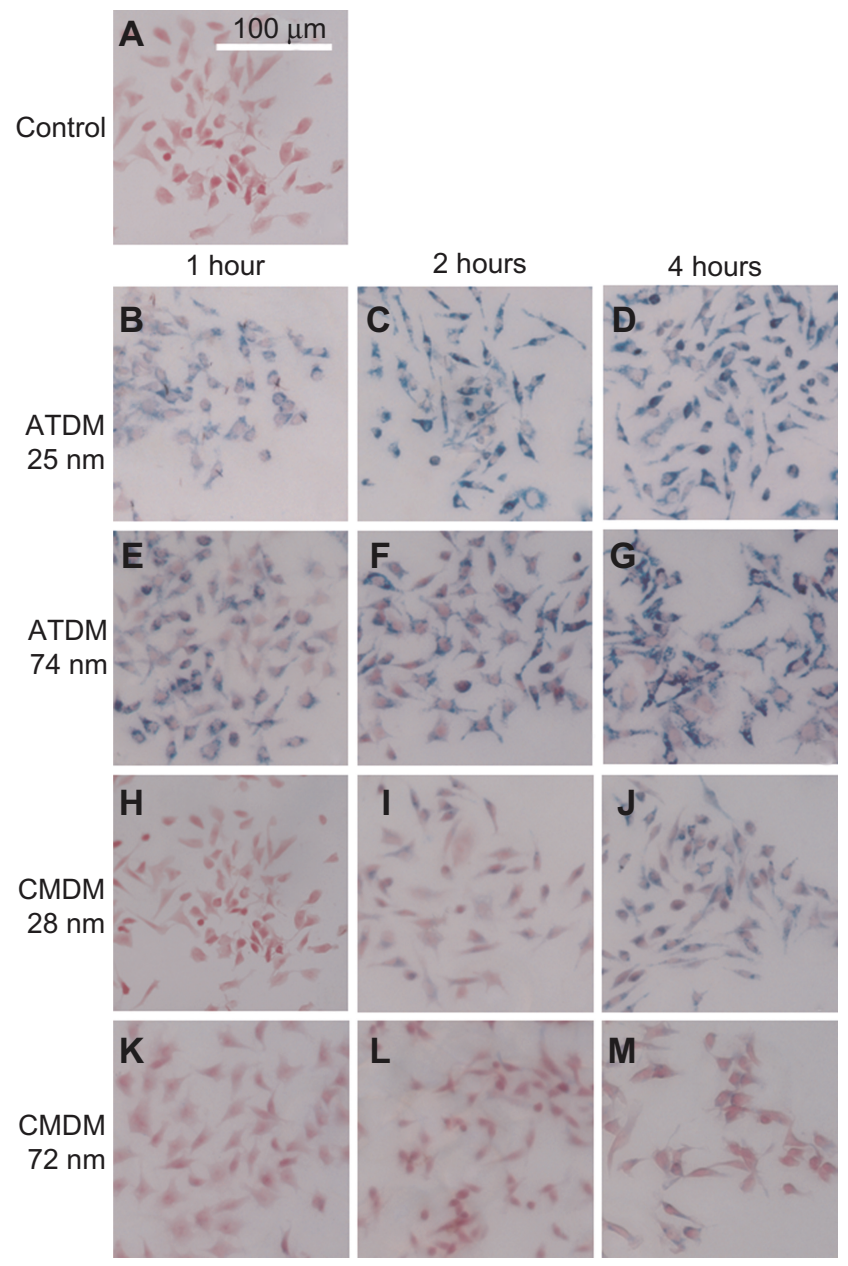

Figure 2 SPIO/USPIO labeled macrophage cells. Microscopy images of labeled cells by ATDM and CMDM. Iron particles are stained blue, and RAW264 macrophage cell are stained red. (A) Unlabeled control cells; (B) ATDM $28 \mathrm{~nm}$ labeled cells at I $\mathrm{h}$ administration; (C) ATDM $28 \mathrm{~nm}$ labeled cells at $2 \mathrm{~h}$ administration; (D) ATDM $28 \mathrm{~nm}$ labeled cells at $4 \mathrm{~h}$ administration; (E) ATDM $74 \mathrm{~nm}$ labeled cells at I $\mathrm{h}$ administration; (F) ATDM $74 \mathrm{~nm}$ labeled cells at $2 \mathrm{~h}$ administration; (G) ATDM $74 \mathrm{~nm}$ labeled cells at $4 \mathrm{~h}$ administration; (H) CMDM $28 \mathrm{~nm}$ labeled cells at I h administration; (I) CMDM $28 \mathrm{~nm}$ labeled cells at $2 \mathrm{~h}$ administration; (J) CMDM $28 \mathrm{~nm}$ labeled cells at $4 \mathrm{~h}$ administration; (K) CMDM $72 \mathrm{~nm}$ labeled cells at I h administration; (L) CMDM $72 \mathrm{~nm}$ labeled cells at $2 \mathrm{~h}$ administration; (M) CMDM $72 \mathrm{~nm}$ labeled cells at $4 \mathrm{~h}$ administration.

Abbreviations: SPIO, superparamagnetic iron oxide; USPIO, ultrasmall superparamagnetic iron oxide; ATDM, alkali-treated dextran magnetite; CMDM, carboxymethyl dextran magnetite.
A

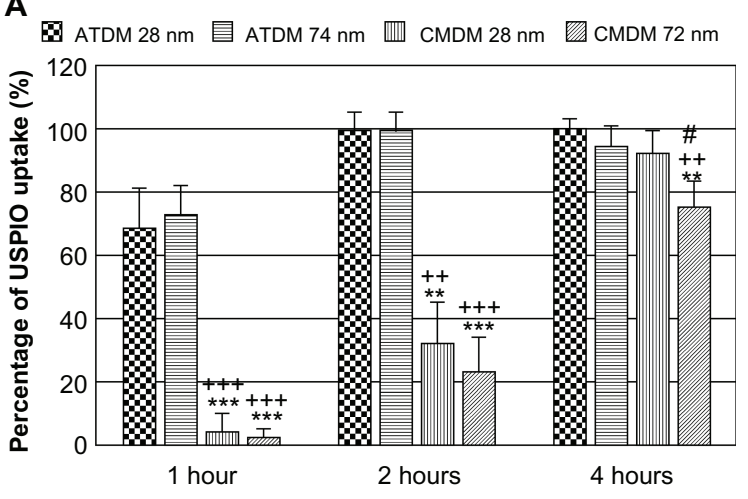

B

Control BATDM $28 \mathrm{~nm}$ 自 ATDM $74 \mathrm{~nm}$ 四 CMDM $28 \mathrm{~nm}$ CMDM $72 \mathrm{~nm}$

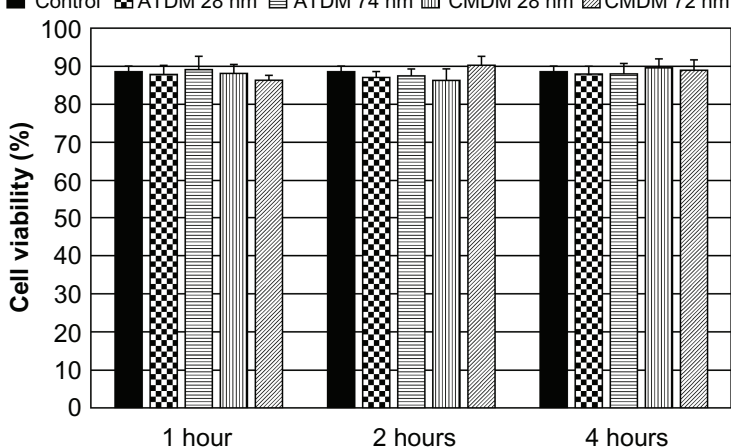

Figure 3 Labeling efficiency and viability in macrophage cells after SPIO/USPIO administrations. (A) Percentage of SPIO/USPIO uptake after SPIO/USPIO administration at I to $4 \mathrm{~h}$. (B) Cell viability after each SPIO/USPIO culture.

Notes: ${ }^{*} P<0.01$, significant difference vs ATDM $28 \mathrm{~nm}$. ${ }^{* * * *} P<0.001$, significant difference vs ATDM $28 \mathrm{~nm}$. ${ }^{++} P<0.01$, significant difference vs ATDM $74 \mathrm{~nm}$. ${ }^{+++} P<0.00$ I, significant difference vs ATDM $74 \mathrm{~nm}$. ${ }^{\# P}<0.05$, significant difference vs CMDM $28 \mathrm{~nm}$.

Abbreviations: SPIO, superparamagnetic iron oxide; USPIO, ultrasmall superparamagnetic iron oxide; ATDM, alkali-treated dextran magnetite; CMDM, carboxymethyl dextran magnetite.

the percentage of macrophages labeled within $200-\mathrm{mm}^{2}$ fields, and the rate of culture saturation over time. Overall, the ATDM-coated nanoparticles provided a more efficient labeling of the macrophages than the CMDM-coated nanoparticles (Figure 2). Quantitative analysis revealed that more than $60 \%$ of the macrophages were labeled by ATDM-coated nanoparticles after $1 \mathrm{~h}$, compared to $<10 \%$ with CMDM-coated nanoparticles, regardless of the particle size (Figure 3A). This profile was maintained after $2 \mathrm{~h}$. However, the efficiency of ATDM-coated nanoparticle labeling had reached $100 \%$, and CMDM-coated nanoparticles were detected only in $20 \%-30 \%$ of macrophages. After 4 $\mathrm{h}$, all nanoparticle formulations had a labeling efficiency superior to $95 \%$, except for $20 \%-30 \%$ for CMDM-coated 28 and $72 \mathrm{~nm}$ nanoparticles. Figure 3B shows that none of the nanoparticle formulations affected the viability of the macrophages. Altogether, these data suggest that the use of 


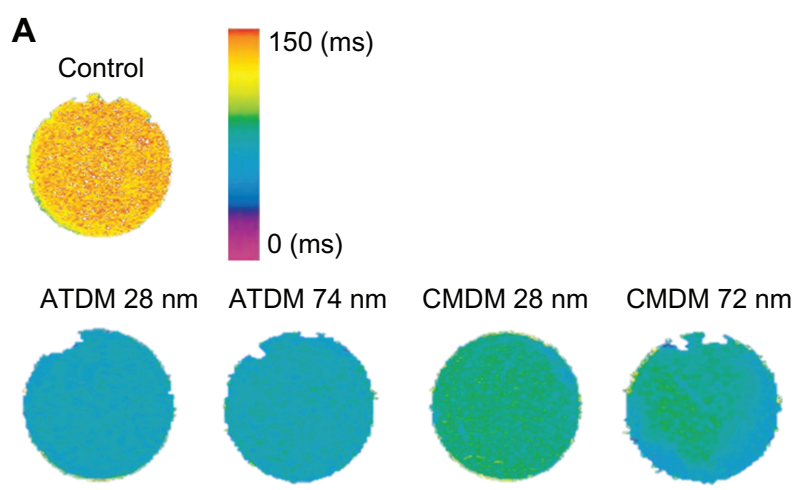

B

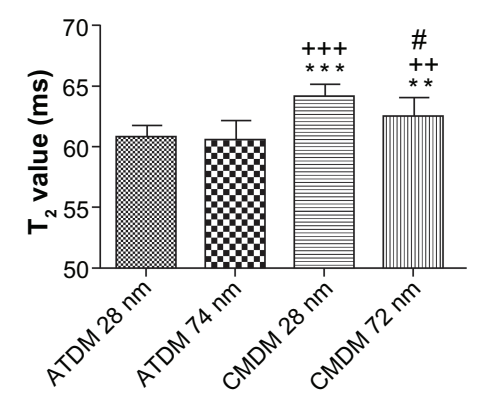

Figure $4 T_{2}$ relaxation times of labeled cells evaluated by MRI. (A) $T_{2}$ map of control and SPIO/USPIO labeled cell pellets at $30 \mathrm{~min}$ cell culture. The color scale represents $\mathrm{T}_{2}$ values from $0 \mathrm{~ms}$ to $150 \mathrm{~ms}$. (B) $\mathrm{T}_{2}$ values of cells labeled by the four SPIO/USPIO. Notes: ${ }^{* *} P<0.0$ I, significant difference vs ATDM $28 \mathrm{~nm}$. ${ }^{* * *} P<0.001$, significant difference vs ATDM $28 \mathrm{~nm} .{ }^{++} P<0.01$, significant difference vs ATDM $74 \mathrm{~nm}$. ${ }^{+++} P<0.00$ I, significant difference vs ATDM $74 \mathrm{~nm}$. ${ }^{\sharp} P<0.05$, significant difference vs CMDM $28 \mathrm{~nm}$

Abbreviations: MRI, magnetic resonance imaging; ATDM, alkali-treated dextran magnetite; CMDM, carboxymethyl dextran magnetite; SPIO, superparamagnetic iron oxide; USPIO, ultrasmall superparamagnetic iron oxide.

USPIO nanoparticles ( $28 \mathrm{~nm}$ ), instead of SPIO nanoparticles (72 and $74 \mathrm{~nm}$ ), does not improve the labeling efficiency of macrophages. In contrast, ATDM coating provides a more rapid and efficient labeling of most cells for at least $4 \mathrm{~h}$, which is an asset for MRI imaging.

\section{Magnetic resonance imaging of labeled mouse macrophage cells}

The $T_{2}$ relaxation time of each nanoparticle formulation was measured following a 30-min labeling period of the macrophages to determine the impact of cellular uptake. Figure 4A shows the different MRI signal intensities obtained for the four types of nanoparticles. Quantitative analysis revealed significantly higher $\mathrm{T}_{2}$ values for the CMDM-coated particles than the ATDM-coated particles (Figure 4B). Among the ATDM-coated particles, USPIO particles generated an even brighter signal change than the SPIO particles. These data suggest that ATDM-coated USPIO particles would offer the best MRI image contrast than all four formulations.
A
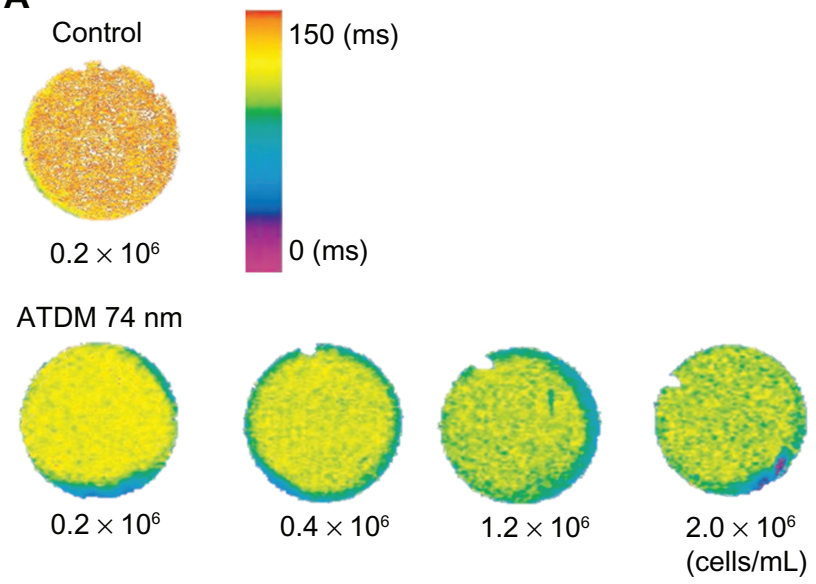

B

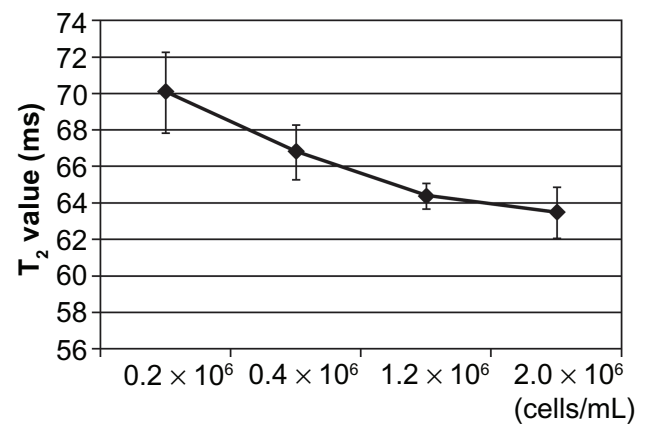

Figure $5 \mathrm{~T}_{2}$ relaxation times of different labeled cell density using ATDM-74 nm. (A) $\mathrm{T}_{2}$ map of control and ATDM $74 \mathrm{~nm}$ labeled cell pellets at $30 \mathrm{~min}$; cell culture at different cell density. The color scale represents $T_{2}$ values from $0 \mathrm{~ms}$ to $150 \mathrm{~ms}$. (B) $T_{2}$ values of labeled cells at different cell density.

Abbreviation: ATDM, alkali-treated dextran magnetite.

Finally, the impact of cell density on the contrast quality of MRI images was tested by measuring the $T_{2}$ relaxation time of macrophages labeled with ATDM-coated $74 \mathrm{~nm}$ nanoparticles for $30 \mathrm{~min}$. Figure $5 \mathrm{~A}$ shows that the $\mathrm{T}_{2}$ relaxation time decreases with increasing cell density. A linear relationship between relaxation time and cell density was observed for $<0.4 \times 10^{6}$ macrophages per $\mathrm{mL}$ (Figure 5B). These data suggest that the ability of MRI negative contrast agent is increased at high cell density.

\section{Discussion}

The present study suggests that SPIO/USPIO labeling efficiency in cultured mouse macrophages was influenced by the particle size and surface coating. The labeling efficiencies of four SPIO/USPIOs in mouse macrophage cells could be visualized by microscopy and 11.7-T MRI.

Oude Engberink et al reported that SPIO particles with a diameter of $150 \mathrm{~nm}$ were more efficiently incorporated into mononuclear cells than USPIO particles with a diameter of $30 \mathrm{~nm} .{ }^{19}$ Particles with larger diameters were more efficiently incorporated into macrophages. ${ }^{21,22}$ After 1 to $4 \mathrm{~h}$ of admin- 
istration, there were no differences in labeling efficiencies between ATDM at $28 \mathrm{~nm}$ and at $74 \mathrm{~nm}$ (Figure 3A). In addition, there was no difference in labeling efficiencies by CMDM $1 \mathrm{~h}$ after administration. The diameter of SPIO used in previous studies was over $150 \mathrm{~nm} .^{21,22}$ The diameter of USPIO used as a control was below $30 \mathrm{~nm}^{23,24}$ The culture time varied from $30 \mathrm{~min}^{21}$ to $6 \mathrm{~h}^{8}$ In our experiment, the diameters of USPIO and SPIO particles that were compared were only about 30 and $70 \mathrm{~nm}$ and we show that particle size is not an important factor in the uptake of 28 and $74 \mathrm{~nm}$ iron nanoparticles irons.

Using an efficient labeling contrast agent is critical for cell imaging. The most commonly used cell-labeling method is to culture cells with a contrast agent. This method employs surface modification with cations, ${ }^{25}$ virus transfection, ${ }^{26}$ lipofectamine, ${ }^{27}$ and poly-L-lysine ${ }^{28}$ to increase the labeling efficiency. These positively-charged reagents are cocultured with negatively-charged USPIO to alter the USPIO into a positively-charged compound. Such a charge alteration increases the affinity of USPIO to negatively-charged cell membranes, thereby facilitating the intracellular uptake of the USPIO contrast agent. The mechanism through which the positively-charged contrast agent passes through the cell membrane remains unclear, however, it may include cell wall destruction, adhesion, and internalization. The ATDMcoated particles are more positively-charged compared to the CMDM-coated particles. Our experiment demonstrated a more efficient uptake of iron particles during approximately $0.5-4 \mathrm{~h}$ culture for more positively-charged ATDM $(-15 \mathrm{mV})$ than for CMDM $(-24 \mathrm{mV})$. Furthermore, in vitro 11.7-T MRI of labeled cells also demonstrated a shorter $\mathrm{T}_{2}$ relaxation time for ATDM-labeled than for CMDM-labeled cells, although CMDM and ATDM had the same diameter (Figure 4B). The different charge and coating states of the surface potential may have influenced the uptake by cultured macrophages.

Surface coating can influence the cytotoxic nature of the nanoparticle. In a previous study, it has been shown that aminosilane- and dextran-coated nanoparticles did not affect the cell viability of mouse macrophage cells. ${ }^{29}$ However, silane-coated SPIO nanoparticles negatively affected mouse macrophage cell viability in a dose-dependent manner. ${ }^{29}$ Moreover, silica-coated SPIO nanoparticles, rather than dextran-coated nanoparticles, displayed dose-dependent cytotoxicity. ${ }^{30}$ In our study, none of the nanoparticle formulations affected the viability of the macrophages (Figure 3B). Our dextran-coated nanoparticles are safer than nanoparticles coated with aminosiline and silica. ${ }^{29,30}$ The different charge and coating states of the surface potential did not influence the cell viability of cultured macrophages in the four types of SPIO and USPIO contrast agents that we used.

In the in vivo imaging of labeled macrophages, a longer half-life of blood is critical for increasing accessibility to target organs and tissues. ${ }^{7,8,28,29}$ SPIO particles with a diameter of about $50 \mathrm{~nm}$ are rapidly incorporated into Kupffer cells in the liver and reticuloendothelial system in the spleen. Hence, the half-life of SPIO in the blood is as short as approximately 4-8 min. ${ }^{13,28}$ On the other hand, USPIO particles with a diameter below $30 \mathrm{~nm}$ are barely recognized by the reticuloendothelial system. The half-life of USPIO in blood is as long as approximately $24-36 \mathrm{~h}$ in humans and a few hours in rats. ${ }^{6,731}$ The current study shows that CMDM-coated nanoparticles label macrophages at a significantly lower rate than ATDM-coated nanoparticles, suggesting that they should remain soluble in blood circulation for a longer period of time. There are no differences in $\mathrm{T}_{2}$ relaxation time of labeled cells between ATDM at 28 and $74 \mathrm{~nm}$ (Figure 4B); however, the $\mathrm{T}_{2}$ relaxation time of contrast agent differs between ATDM at 28 and $74 \mathrm{~nm}$ (Figure 1). Hence, the shortened $\mathrm{T}_{2}$ relaxation time of labeled cells cannot simply be explained by the difference in the labeling efficiency of cells. Also, no difference was noted in the $\mathrm{T}_{2}$ relaxation time of contrast agent between ATDM at 28 and CMDM $28 \mathrm{~nm}$ (Figure 1), even though the $\mathrm{T}_{2}$ relaxation times of ATDM labeled cells were shorter than that of CMDM labeled cells (Figure 4B). Thus, ATDM USPIO with a smaller diameter was more efficiently incorporated into cells than CMDM USPIO, thereby providing a more effective in vivo contrast agent for macrophages.

\section{Conclusion}

We conclude that the best contrast agent would be ATDMcoated $74 \mathrm{~nm}$ SPIO nanoparticles. Despite recent interest in smaller particles (USPIO), this study shows that coating plays a more important role than size to optimize MRI contrast, while increasing the nanoparticle labeling time.

\section{Disclosure}

The authors report no conflicts of interest in this work.

\section{References}

1. Daldrup-Link HE, Rudelius M, Piontek G, et al. Migration of iron oxidelabeled human hematopoietic progenitor cells in a mouse model: in vivo monitoring with 1.5-T MR imaging equipment. Radiology. 2005;234(1): 197-205. 
2. Murase K, Oonoki J, Takata H, et al. Simulation and experimental studies on magnetic hyperthermia with use of superparamagnetic iron oxide nanoparticles. Radiol Phys Technol. 2011;4(2):194-202.

3. Mori Y, Umeda M, Fukunaga M, Ogasawara K, Yoshioka Y. MR contrast in mouse lymph nodes with subcutaneous administration of iron oxide particles: size dependency. Magn Reson Med Sci. 2011;10(4):219-227.

4. McBain SC, Yiu HH, Dobson J. Magnetic nanoparticles for gene and drug delivery. Int J Nanomedicine. 2008;3(2):169-180.

5. Benderbous S, Corot C, Jacobs P, Bonnemain B. Superparamagnetic agents: physicochemical characteristics and preclinical imaging evaluation. Acad Radiol. 1996;3 Suppl 2:S292-S294.

6. Di Marco M, Sadun C, Port M, Guilbert I, Couvreur P, Dubernet C. Physicochemical characterization of ultrasmall superparamagnetic iron oxide particles (USPIO) for biomedical application as MRI contrast agents. Int J Nanomedicine. 2007;2(4):609-622.

7. Dousset V, Delalande C, Ballarino L, et al. In vivo macrophage activity imaging in the central nervous system detected by magnetic resonance. Magn Reson Med. 1999;41(2):329-333.

8. Josephon L, Tung CH, Moore A, Weissleder R. High-efficiency intracellular magnetic labeling with novel superparamagnetic-Tat peptide conjugates. Bioconjug Chem. 1999;10(2):186-191.

9. Stoll G, Wesemeier C, Gold R, Solymosi L, Toyka KV, Bendszus $M$. In vivo monitoring of macrophage infiltration in experimental autoimmune neuritis by magnetic resonance imaging. J Neuroimmunol. 2004;149(1-2):142-146.

10. Jo SK, Hu X, Kobayashi H, et al. Detection of inflammation following renal ischemia by magnetic resonance imaging. Kidney Int. 2003;64(1): 43-51.

11. Kanno S, Lee PC, Dodd SJ, Williams M, Griffith BP, Ho C. A novel approach with magnetic resonance imaging used for the detection of lung allograft rejection. J Thorac Cardiovasc Surg. 2000;120(5):923-934.

12. Tang T, Howarth SP, Miller SR, et al. Assessment of inflammatory burden contralateral to the symptomatic carotid stenosis using highresolution ultrasmall, superparamagnetic iron oxide-enhanced MRI. Stroke. 2006;37(9):2266-2270.

13. Trivedi RA, Mallawarachi C, U-King-Im JM, et al. Identifying inflamed carotid plaques using in vivo USPIO-enhanced MR imaging to label plaque macrophages. Arterioscler Thromb Vasc Biol. 2006;26(7): 1601-1606.

14. Weissleder R, Stark DD, Engelstad BL, et al. Superparamagnetic iron oxide: pharmacokinetics and toxicity. AJR Am J Roentgenol. 1989; 152(1):167-173

15. Corot C, Robert P, Idee JM, Port M. Recent advances in iron oxide nanocrystal technology for medical imaging. Adv Drug Deliv Rev. 2006; 58(14):1471-1504.

16. Wang YX, Hussain SM, Krestin GP. Superparamagnetic iron oxide contrast agents: physicochemical characteristics and applications in MR imaging. Eur Radiol. 2001;11(11):2319-2331.
17. Oishi K, Noguchi H, Saito H, et al. Cell labeling with a novel contrast agent of magnetic resonance imaging. Cell Transplant. 2010; 19(6):887-892.

18. Bowen CV, Zhang X, Saab G, Gareau PJ, Rutt BK. Application of the static dephasing regime theory to superparamagnetic iron-oxide loaded cells. Magn Reson Med. 2002;48(1):52-61.

19. Oude Engberink RD, van der Pol SM, Dopp EA, de Vries HE, Blezer EL. Comparison of SPIO and USPIO for in vitro labeling of human monocytes: MR detection and cell function. Radiology. 2007;243(2):467-474.

20. Matsushita T, Kusakabe Y, Fujii H, Murase K, Yamazaki Y. Inflammatory imaging with ultrasmall superparamagnetic iron oxide. Magn Reson Imaging. 2011;29(2):173-178.

21. Daldrup-Link HE, Rudelius M, Oostendorp RA, et al. Targeting of hematopoietic progenitor cells with MR contrast agents. Radiology. 2003;228(3):760-767.

22. Matuszewski L, Persigehl T, Wall A, et al. Cell tagging with clinically approved iron oxides: feasibility and effect of lipofection, particle size, and surface coating on labeling efficiency. Radiology. 2005;235(1): $155-161$.

23. Weissleder R, Cheng HC, Bogdanova A, Bogdanov A Jr. Magnetically labeled cells can be detected by MR imaging. J Magn Reson Imaging. 1997;7(1):258-263.

24. Schoepf U, Marecos EM, Melder RJ, Jain RK, Weissleder R. Intracellular magnetic labeling of lymphocytes for in vivo trafficking studies. Biotechniques. 1998;24(4):642-646, 648-651.

25. Frank JA, Miller BR, Arbab AS, et al. Clinically applicable labeling of mammalian and stem cells by combining superparamagnetic iron oxides and transfection agents. Radiology. 2003;228(2):480-487.

26. Wunderbaldinger P, Josephon L, Weissleder R. Tat peptide directs enhanced clearance and hepatic permeability of magnetic nanoparticles. Bioconjug Chem. 2002;13(2):264-268.

27. Bulte JW, Kraitchman DL. Iron oxide MR contrast agents for molecular and cellular imaging. NMR Biomed. 2004;17(7):484-499.

28. Bulte JW, Vymazal J, Brooks RA, Pierpaoli C, Frank JA. Frequency dependence of MR relaxation times. II. Iron oxides. J Magn Reson Imaging. 1993;3(4):641-648.

29. Zhu XM, Wang YX, Leung KC, et al. Enhanced cellular uptake of aminosilane-coated superparamagnetic iron oxide nanoparticles in mammalian cell lines. Int J Nanomedicine. 2012;7:953-964.

30. Kunzmann A, Andersson B, Vogt C, et al. Efficient internalization of silica-coated iron oxide nanoparticles of different sizes by primary human macrophages and dendritic cells. Toxicol Appl Pharmacol. 2011; 253(2):81-93.

31. Majumdar S, Zoghbi SS, Gore JC. Pharmacokinetics of superparamagnetic iron-oxide MR contrast agents in the rat. Invest Radiol. 1990;25(7): $771-777$.
International Journal of Nanomedicine

\section{Publish your work in this journal}

The International Journal of Nanomedicine is an international, peerreviewed journal focusing on the application of nanotechnology in diagnostics, therapeutics, and drug delivery systems throughout the biomedical field. This journal is indexed on PubMed Central, MedLine, CAS, SciSearch $®$, Current Contents ${ } /$ Clinical Medicine,

\section{Dovepress}

Journal Citation Reports/Science Edition, EMBase, Scopus and the Elsevier Bibliographic databases. The manuscript management system is completely online and includes a very quick and fair peer-review system, which is all easy to use. Visit http://www.dovepress.com/ testimonials.php to read real quotes from published authors. 